International Journal of Life Sciences
Available online at http://sciencescholar.us/journal/index.php/ijls
Vol. 3 No. 1, April 2019, pages: $25 \sim 30$
e-ISSN: 2550-6986, p-ISSN: $2550-6994$
https://doi.org/10.29332/ijls.v3n1.243

\title{
Effects of Replacement of Fish Mill with Golden Snail Mill in Ration to Performance of Male Bali Duck
}

\author{
(1)
}

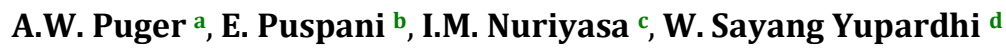

Article history: Received 18 July 2018, Accepted: 31 December 2018, Published: 29 January 2019

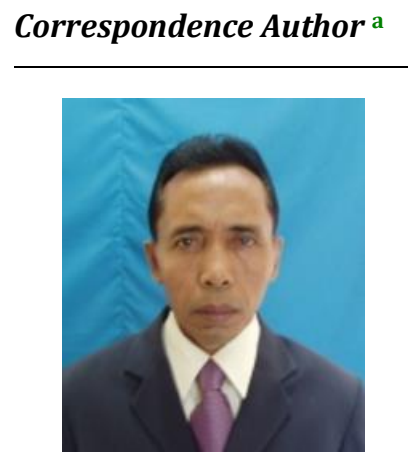

Keywords

animal;

Bali duck;

fish mill;

golden snail mill;

performance;

\begin{abstract}
The research objective was to know the performance of male Bali duck fed ration half or all replacement of fish mill with golden snail mill. The research results showed that initial body weight of the animals fed ration without replacement of fish mill (R0), replacement $25 \%$ fish mill with golden snail mill (R1), replacement 50\% fish mill with golden snail mill (R2), replacement $75 \%$ fish mill with golden snail mill (R3) and replacement $100 \%$ fish mill with golden snail mill (R4) were $610.00 \mathrm{~g}, 604.25 \mathrm{~g}, 607.75 \mathrm{~g}, 591.50 \mathrm{~g}$ and $615.50 \mathrm{~g}$ respectively which was statistically no significant difference $(\mathrm{P}>0.05)$. End body weight and body weight gain of the animals fed treatment ration R3 and $\mathrm{R} 4$ were a lower significant difference $(\mathrm{P}<0.05)$ than on the animals fed R2, R1, and $\mathrm{R} 0$. There was no significant difference $(\mathrm{P}<0.05)$ on the variable of ration consumption and ration conversion of the animals fed ration fish mill replacement with golden snail mill on a different level. From the research results could be concluded that fish mill in ration could be replaced with golden snail mill up to $50 \%$ without decreased of the animal performance.
\end{abstract}

e-ISSN: 2550-6986, p-ISSN: 2550-6994@C Copyright 2019. The Author. SS Journals Published by Universidad Técnica de Manabí. This is an open-access article under the CC BY-SA 4.0 license (https://creativecommons.org/licenses/by-sa/4.0/) All rights reserved.

\section{Contents}

Abstract

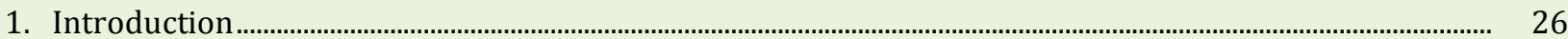

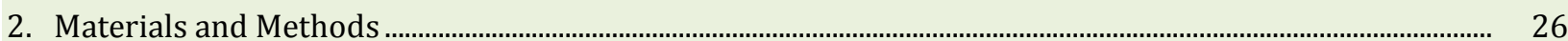

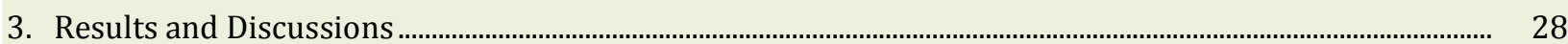

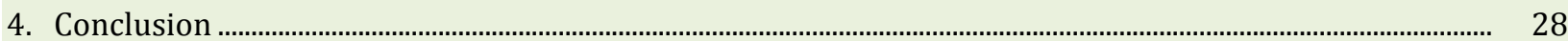

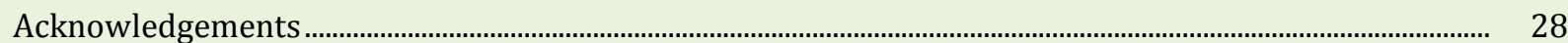

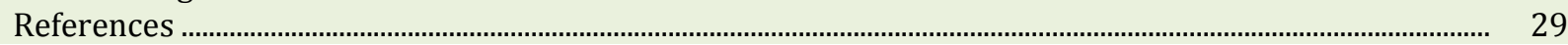

a Faculty of Animal Science, Udayana University, Denpasar, Indonesia

b Faculty of Animal Science, Udayana University, Denpasar, Indonesia

c Faculty of Animal Science, Udayana University, Denpasar, Indonesia

d Faculty of Animal Science, Udayana University, Denpasar, Indonesia 


\section{Introduction}

Diversification of meat consumption is needed to accelerate animal protein self-government for Indonesia society. Development of cattle, goat, buffalo, and horse need a broad area, and because of their reproduction level are low, those must be pay more attention in their development in the future. The other ways are chicken and pig farms, but their feeds are expensive; these also a dilemma because there is a competition between a human being and the animals. Duck is one of the potential alternative animal to develop because it easy to rear, more resistant to disease and can use ingredient source of protein which is a rice disease for farmers, golden snail (Cairina Moschata).

Up to now, the obstacle of duck development is low knowledge of farmers about ration quality. Besides that, duck rear traditionally and whims system causes low development of the animal. One of the efforts to increase its productivity can be done through the rear of the intensive system. This system obstacle i.e. cost of ration particularly ingredient source of protein such as fish mill and soybean mill are still expensive. The ration is the most factors affects animal growth rate, but the cost of the ration is the highest portion about 60 $70 \%$ of total production. Nuriyasa et al., (2015), stated that waste or material that not use optimally yet can diminish production cost and help the government to create a clean environment farm.

The golden snail is a disease of rice plant since on the age of 10 days after planting. The loss of the snail attack was about $16-40 \%$ total production. But, it is very potential to replace fish mill in duck ration. Nutrient content of golden snail mill is crude protein $46.2 \%$, metabolite energy $1920 \mathrm{kcal} / \mathrm{kg}$, Calcium $2.9 \%$ and phosphor 0,3\%. Research results of Purnamaningsih (2010), showed that the use of golden snail mill up to $9 \%$ in duck ration was no affects to duck egg quality. Furthermore, research results of Sulistiono (2007), found that golden snail mill 10\% fed to duck could increase growth rate and egg production up to $80 \%$.

\section{Materials and Methods}

Duck

The research used 40 male Bali Duck on the age of 4 weeks that were bought from a duck farmer at Mengwi village, Badung regency.

Pen

The research used litter pen with a size of $60 \mathrm{~cm}$ length, 40 wide and $50 \mathrm{~cm}$ height.

\section{Research Design}

The research used Randomized Block Design (RBD), with 5 treatments and 4 blocks (replicates). Ration treatment $(\mathrm{R})$ consists of:

R0: use of $15 \%$ fish mill in ration as a control treatment

R1: Replacement 25\% fish mill with golden snail mill

R2: Replacement 50\% fish mill with golden snail mill

R3: Replacement 75\% fish mill with golden snail mill

R4: Replacement $100 \%$ fish mill with golden snail mill

Ration

Ration composition and its nutrient content of the research is shown in Table 1 and Table 2. 
Table 1

The composition of the research ration

\begin{tabular}{llllll}
\hline \multirow{2}{*}{ Ingredient (\%) } & \multicolumn{5}{c}{ Treatment } \\
\cline { 2 - 6 } & $\mathrm{R} 0$ & $\mathrm{R} 1$ & $\mathrm{R} 2$ & $\mathrm{R} 3$ & $\mathrm{R} 4$ \\
\hline Yellow corn & 51,15 & 51,05 & 52,15 & 52,45 & 54,60 \\
Coconut mill & 4,70 & 6,45 & 8,55 & 9,35 & 14,60 \\
Rice bran & 28,15 & 25,50 & 21,75 & 19,70 & 11,95 \\
Coconut oil & 1,00 & 2,00 & 2,55 & 3,50 & 3,85 \\
Golden snail mill & 0,00 & 3,75 & 7,50 & 11,25 & 15,00 \\
Fish mill & 15,00 & 11,25 & 7,50 & 3,75 & 0,00 \\
Total & 100,00 & 100,00 & 100,00 & 100,00 & 100,00 \\
\hline
\end{tabular}

Table 2

Ration nutrition content of the research

\begin{tabular}{lllllll}
\hline \multirow{2}{*}{ Nutrient } & \multicolumn{5}{c}{ Treatment } & \multirow{2}{*}{ NRC (1994) } \\
\cline { 2 - 6 } & R0 & R1 & R2 & R3 & R4 & \\
\hline ME (k cal/kg) & $2.901,98$ & $2.906,64$ & $2.900,50$ & $2.909,49$ & $2.904,85$ & $2.900,00$ \\
Crude protein (\%) & 16,00 & 16,02 & 16,08 & 16,01 & 16,03 & 16,00 \\
Crude fat (\%) & 9,59 & 9,75 & 9,38 & 9,57 & 8,57 & 5,00 \\
Crude fiber (\%) & 5,26 & 5,34 & 5,38 & 5,40 & 5,45 & 4,00 \\
Ca (\%) & 0,87 & 0,78 & 0,68 & 0,59 & 0,50 & 0,60 \\
P (\%) & 0,59 & 0,52 & 0,44 & 0,38 & 0,28 & 0,30 \\
Lysine (\%) & 0,83 & 0,75 & 0,67 & 0,59 & 0,50 & 0,65 \\
Metionine + Sistine (\%) & 0,53 & 0,49 & 0,45 & 0,41 & 0,37 & 0,30 \\
\hline
\end{tabular}

\section{Research Variable}

a) Ration Consumption

Ration consumption was calculated every week by deducting the sum of ration fed to the animals with the rest of it at that day. Total ration consumption was obtained by summing up ration consumption every week during the research.

b) Body weight

Body weight was obtained weekly to get body weight gain. Initial body weight was obtained at the beginning of the experiment, while end body weight at the end of the research. The end boy weight minus initial body weight was body weight gain during the research. The animal was fasted 12 hours before weighed.

c) Ration Conversion

Feed Conversion Ratio (FCR) was calculated between the sum of ration consumption and body weight gain during the research.

\section{Data Analysis}

Data of the research were analyzed with multiple range test, if there was significant amongst the treatments $(P<$ 0.05), it would be continued to Duncan's Test (Steel and Torrie (1980).

\section{Research Results}

Initial body weight of male Bali duck fed ration without replacement of fish milk with golden snail mill (control/R0) was $599.5 \mathrm{~g}$, while the animal fed replacement $25 \%$ fish mill with golden snail mill (R1), replacement 50\% fish mill with golden snail mill (R2), replacement 75\% fish mill with golden snail mill (R3),

Puger, A., Puspani, E., Nuriyasa, I., \& Yupardhi, W. S. (2019). Effects of replacement of fish mill with golden snail mill in ration to performance of male Bali duck. International journal of life sciences, 3(1), 25-30. 
and replacement 100\% fish mill with golden snail mill (R4) were 604,25g, 607,75g, 618,0g and 602,67g respectively (Table 3).

Table 3

Performance of Male Bali Duck Fed Ration Replacement of Fish Milk with Golden Snail

\begin{tabular}{lllllll}
\hline \multirow{2}{*}{ Variable } & \multicolumn{5}{c}{ Treatment } & \multirow{2}{*}{ SEM } \\
\cline { 2 - 6 } & R0 & R1 & R2 & R3 & R4 & \\
\hline Initial weight (g) & $599,5 \mathrm{a}$ & $604,25 \mathrm{a}$ & $607,75 \mathrm{a}$ & $618,0 \mathrm{a}$ & $602,67 \mathrm{a}$ & 13,22 \\
End body weight (g) & $1395,0 \mathrm{a}$ & $1399,0 \mathrm{a}$ & $1467,5 \mathrm{a}$ & $1373,5 \mathrm{~b}$ & $1266,67 \mathrm{~b}$ & 27,35 \\
Body weight gain (g) & $795,5 \mathrm{~b}$ & $794,75 \mathrm{ab}$ & $859,75 \mathrm{a}$ & $663 \mathrm{~b}$ & $664,0 \mathrm{ab}$ & 20,37 \\
Ration consumption (g) & $2768,34 \mathrm{a}$ & $2775,05 \mathrm{a}$ & $2957,54 \mathrm{a}$ & $2373,54 \mathrm{a}$ & $2430,24 \mathrm{a}$ & 74,37 \\
Ration conversion & $3,48 \mathrm{a}$ & $3,49 \mathrm{a}$ & $3,44 \mathrm{a}$ & $3,58 \mathrm{a}$ & $3,66 \mathrm{a}$ & 0,13 \\
\hline
\end{tabular}

R0: ration used $15 \%$ fish mill

R1: replacement $25 \%$ fish mill with golden snail mill

R2: replacement $50 \%$ fish mill with golden snail mill

R3: replacement $75 \%$ fish mill with golden snail mill

R4: replacement $100 \%$ fish mill with golden snail mill

\section{Results and Discussions}

The end body weight of the animals fed treatment R4 was the lowest (1266.67 g), while the animals fed ration R3 was $8.43 \%$ higher ( $\mathrm{P}>0.05$ ) compare to it. Furthermore rations R2, R1 and R0 were 15.85\%, $10.44 \%$ and $10.13 \%$ respectively higher $(\mathrm{P}<0.05)$ than $\mathrm{R} 4$. Those were due to the animal fed R4 and R3 consumed lower ration than the animals fed ration R3, R1, and R0. The lower ration consumption on treatment R3 and R4 might be due to less palatability of those rations compare to R2, R1, and R0. Lysine and methionine amino acids content in ration R3 and R4 were lower than treatment R3, R1 and R0 (Table 2), and much lower than standard need, so meat tissue composed disturbance. Low lysine and methionine amino acids content in treatment R3 and R4 were also caused body weight gain of the animals fed ration R3, R4 was lower than R2, R1, and R0 as Table 3.

The animal fed ration control (R0) consumed the highest ration $2957.54 \mathrm{~g}$, while on the animals fed ration R1, R0, R3, and R4 were 2775.05g, 2768.34g, 2373.54g and 2430.24g respectively, but statistically no significant difference $(\mathrm{P}>0.05)$ than $\mathrm{R} 2$. This was due to similar energy and protein of treatment ration, match to opinions of Tillman (1978) and Nuriyasa et al., (2016). Ration conversion of the animal fed control ration treatment (R0) was 3.48 no significant difference (P > 0.05) compare to R1 (3.49), R2 (3.44), R3 (3.58) and R4 (3.66). This was due to higher body weight that needs higher ration consumption and not because of the different efficiency use of nutrition (Nuriyasa et al., 2017).

\section{Conclusion}

From the research results could be concluded that fish mill in ration could be replaced with golden snail mill up to $50 \%$ without decreased of the animal performance.

\section{Acknowledgments}

The authors thank LP3M Udayana University to help the budget of the research. Next to the Rector of Udayana University, the Dean of Faculty of Animal Science Udayana University for their help in provided various facilities for the research, so it could be done accordingly. 


\section{References}

Nuriyasa, I. M., Mastika, I. M., \& Dewi, G. A. M. K. (2015). Performance of local rabbit (Lepus nigricollis) fed diets containing different level of fermented coffee pulp. African Journal of Agricultural Research, 10(52), 4820-4824. https://doi.org/10.5897/AJAR2015.10357

Nuriyasa, I. M., Puspani, E., \& Yupardhi, W. S. (2018). Growth and blood profile of lepus nigricollis fed diet fermented coffee skin in different levels. International Journal of Life Sciences,2(1), 21-28. https://doi.org/10.29332/ijls.v2n1.83

Nuriyasa, I. M., Puspani, E., \& Yupardhi, W. S. (2018). Performance and carcass of local rabbit (Lepus nigricollis) fed concentrate on different levels based on carrot leaf waste (Daucus carota L.). International Journal of Life Sciences, 2(3), 13-19. https://doi.org/10.29332/ijls.v2n3.189

Purnamaningsih, R., \& Hutami, S. (2016). Increasing Al-Tolerance of Sugarcane Using Ethyl Methane Sulphonate and In Vitro Selection in the Low pH Media. HAYATI Journal of Biosciences, 23(1), 1-6. https://doi.org/10.1016/j.hjb.2016.01.006

Steel, R. G. D., \& Torrie, J. H. (1980). Principle and procedure of statistic McGraw-Hill New York. NY, 481pp.

Sulastiono. (2007). Management of Golden Snail Mill. (Pomacea Canaliculata). Prosiding. Konferensi Sains Kelautan dan Perikanan Indonesia I. Kampus FPIK, IPB Dramaga, 17-18 July 2007: 124-136.

Tillman, A. D., Ridenour, H. E., \& Getz, W. R. (1986). A guide to the feeding and nutrition of ruminants in the tropics. http://agris.fao.org/agris-search/search.do?recordID=XF2015033242

Puger, A., Puspani, E., Nuriyasa, I., \& Yupardhi, W. S. (2019). Effects of replacement of fish mill with golden snail mill in ration to performance of male Bali duck. International journal of life sciences, 3(1), 25-30. https://doi.org/10.29332/ijls.v3n1.243 


\section{Biography of Authors}

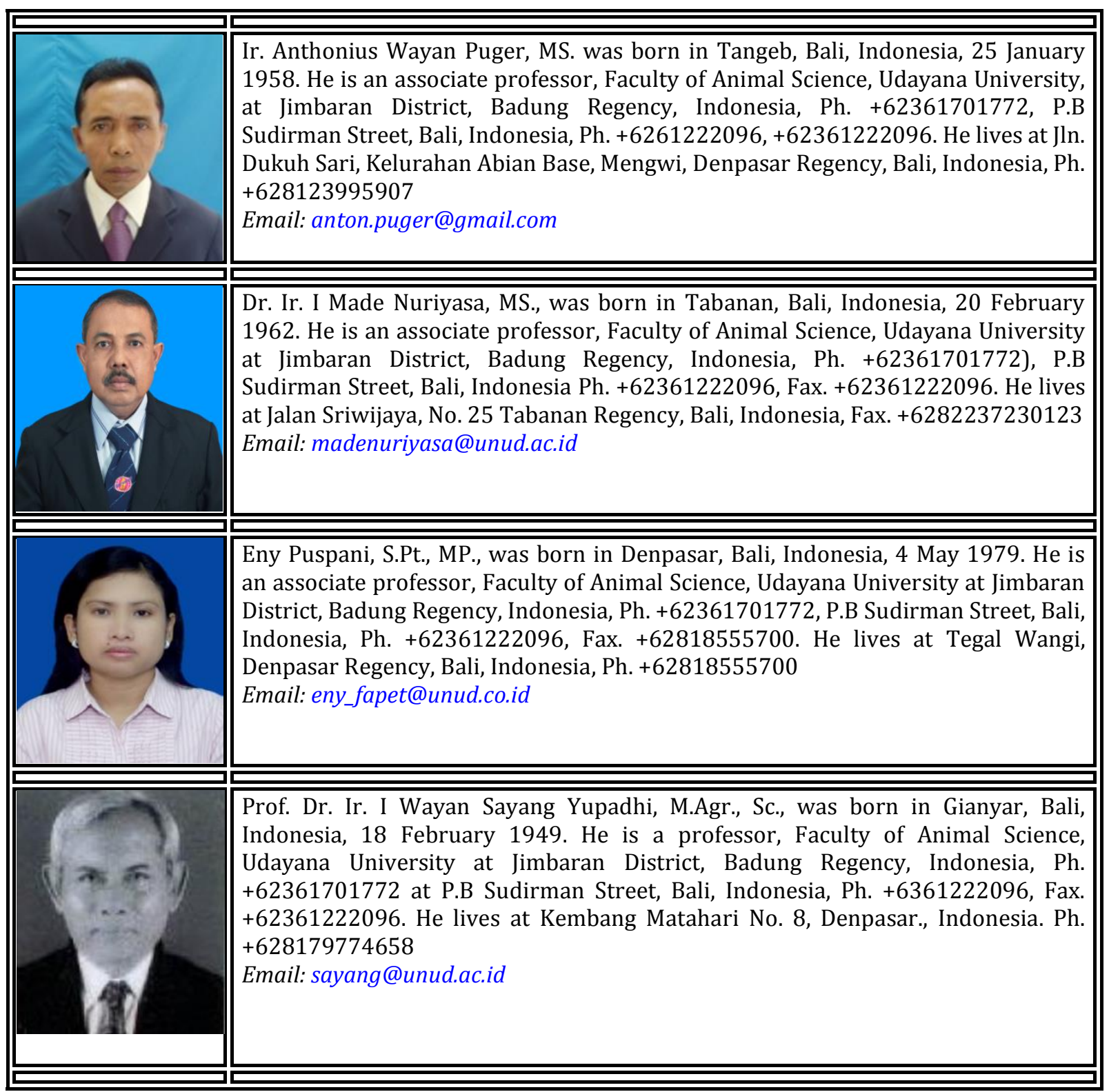

